\title{
Social Interaction: Communicative Approach
}

\author{
Margaryta Zaitseva \\ Department of Foreign Languages No 2, Yaroslav Mudryi National Law University, Ukraine \\ Lyudmyla Pelepeychenko \\ Department of Philology, Translation and Strategic Communications, National Academy of the National Guard of \\ Ukraine, Ukraine
}

\begin{abstract}
The article focuses on the study of requirements for communication in the social sphere and justification of their specificity in comparison with other types of verbal interaction. The relevance of the stated problem is determined by the significant influence of social communications on society and the dependence of public safety on the effectiveness of social interaction. The study aimed at identifying the types of violations of commonly known maxims in the social sphere and substantiating the specificity of requirements for social communicative interaction. Two main methods were used in the research: projecting and modeling. The well-known communication maxims were divided into two groups. The first group contains those that define the requirements for organizing the content of the message and are aimed at ensuring the fullness of its perception by the addressees. The second group includes maxims, which establish requirements for the moral climate of communication and the implementation of the principle of politeness. The data of interviews given by representatives of governmental bodies to journalists of certain TV channels and blogs, as well as the analysis of Internet news videos revealed the types of violations of the well-known maxims of communication in the social domain. The main ones are: ignoring the maxims of the second group in interviews and non-compliance with the maxims of the first group in news programs. It has been proved that the well-known maxims of communication need to be revised taking into account the conditions of social contact discourse. The specificity of maxims in social communicative interaction was substantiated.
\end{abstract}

Index Terms-social communications, maxims of communication, communicative faults, discourse conditions, universal human values

\section{INTRODUCTION}

Effective social interaction is extremely important in our time, as it ensures social wellbeing, sound activity in all domains of society and, consequently, the development of any country as a whole. The examination of the problems of social interaction in the aspect of communication has not only practical but also theoretical value: it allows for a more profound understanding of the mechanisms of verbal interaction in society, to substantiate the recommendations and requirements necessary for the establishment of mutual understanding. The theoretical basis of the issue of the maxims of communication is so deep and profound that, at first glance, it makes no sense to turn to it again. However, facts of life often indicate not just a violation of well-known maxims of communication, but their ignorance or even complete denial. In addition, inter alia, representatives of authority also derogate from the norms of communication. Despite their meeting, all the necessary criteria (social status, good education, impeccable reputation, sheer civility) they often do not set an example of good communication. Mindful of their publicity, their communication failures become known immediately to the public at large, receive a negative public assessment, and cause discussions at best and social resentment at worst. When teaching students in institutions of higher education, we need to be aware of the fact that some of them are likely to hold powerful senior positions in the future. It may be added at this point that it is not known how many mistakes are made at lower levels of communicative interaction, especially in the discourses of asymmetric communication. Nowadays we have to ascertain the contradiction between the facts of inconsistency of communication maxims in social interaction and the lack of theoretical support for the establishment of harmonious communication in this domain. This reality necessitates addressing a set of problems of social communication, from identifying the specificity of communicative interaction in this sphere, testing the known maxims of communication for their relevance in social discourse to justifying the specificity of maxims in the discursive practices of social contacts. Thus, the problem of identifying the mechanisms of successful communication in the discourses of social contacts is topical. The relevance of the current problems of modernity and the theory of communication, the focus on solving practical problems of successful social interaction testify to the relevance of the topic of this paper.

\section{LITERATURE REVIEW}

The maxims of communication are the requirements that ensure its success. They are substantiated in the works by G. Grice (1975), J. Leech (1983), P. Brown, and S. Levinson (1987). Analyzing the conditions necessary for successful communication, Penelope Brown and Steve Levinson conclude that the key to successful communication is the principle of politeness: it aims at making communication partners feel comfortable, in the terminology of the authors of 
the concept, to avoid "loss of face" (1987). The implementation of this principle is possible in two types of behaviors of communicators - in strategies of positive politeness and negative politeness. The first of these strategies (the authors substantiated them in the number of 15) provide the maximum focus on harmonizing communication, emphasizing interest in the partner, and creating a supportive environment. Negative politeness strategies do not contradict ethical norms but allow communicators to be independent in choosing ways of communicative interaction, not limiting their focus on harmonizing communication. Despite the critical remarks about the term "negative politeness" (it really looks like an oxymoron) and criticism of the theory in general (Eelen, 2014), the term came into the use of the terminological apparatus of communication theory. The authors referred to applied the term "politeness principle" interpreted in the paper both as a principle and as a requirement for communication (i.e., maxim) that implements this principle. Later, the term "cold politeness" was also introduced into scientific usage (Movna komunikatsiia, 2015).

In the light of the above, the maxims of social communication are studied here, so there is a necessity to provide an interpretation of this concept, a fortiori, it is extremely broad (Rizun, 2012; Kholod, 2010). As is well known, this term is used in two main meanings. The first of them is related to the study of an individual's socialization problems, in particular the adaptation to the society of children with speech disorders and the establishment of communicative contacts. This direction is being actively developed by American Speech-Language-Hearing Association (ASHA) (Social Communication, 2021). The second direction concerns the problems of people in society. Our work is performed within the second direction. Its significance has been substantiated in numerous twenty-first century publications.

So, K. Ekman states that "Through social interaction and by sharing resources, members are enabled to engage in productive dialogue where common knowledge is created and scaffolded in the community over time" (2021). J. Robinson writes that the image and reputation of a subject of activity depend on their ability to successfully lead social and communicative interactions (2016).

T. Chaltas considers social communication in two ways: in terms of one-way dissemination of information and in terms of social interaction, which is aimed at cooperation, co-creation (2016). A significant place in modern scientific research is occupied by the issue of implementing strategies of positive politeness in such types of social communication as briefing (Lutsenko, 2016), TV talk shows (Chovganiuk, 2017).

Assuming the position on the interpretation of social communication as a social-communicative interaction, which is noted in the majority of sources, we limit the research material to multifaceted communication. Neither the authorities nor the authors of the news videos know who will watch the relevant TV or Internet content. It means that they must focus on universal values. Communication deviations caused by a violation of the principle of cooperation have been characterised (Prus, 2015). The importance of the Internet as a means of social communication and social influence is demonstrated (Zarytska, 2018).

Thus, the problems of social communicative interaction are in the focus of research these days. Based on literature on theory regarding the topic under research, we have reason to believe that all the prerequisites for identifying the specific nature of maxims in social communication are created. Noting the presence of conditions for further comprehension of the mechanisms of communication, let us draw attention to a lacuna: the question of the specificity of communication maxims in social interaction still remains on the sidelines of scientific comprehension. Taking into account the state of research on the problem, the aim of this article and the specific tasks necessary to achieve it have been formulated.

The aim of the article is to identify the types of violations of the well-known maxims of communication in the social sphere and to substantiate the specificity of the requirements for social communicative interaction.

The underlying hypothesis of the paper is the assumption that the well-known maxims of communication are not always relevant to the social sphere of interaction and need to be corrected given the conditions of discourse.

The basic conceptual idea, which determines the direction of the scientific search, can be formulated as follows: the specificity of the maxims of social communication can be discovered by projecting the content of the well-known maxims of communication onto the social sphere, as well as orienting it towards the conditions of social communication and universal and national priorities of value.

\section{ReSEARCH MethodS AND TECHNIQUES}

Being aware of the fact that the discourse of social-communicative interaction covers a large number of facts of communication in this area, which cannot be analyzed within the same article, we reduced our research by two forms of verbal contact available on the Internet. The first form is an interview given by government officials to journalists on TV channels or blogs. The second form - videos with news posted on the Internet.

The choice of these types of material is not random. Our point here is that interview is a speech that is not prepared in advance. Interviewees are usually told the topic of the interview but not the specific questions, i.e. the authorities do not know what questions the interviewers will ask. Even assuming that the questions are known in advance, the respondents will answer them orally, not according to a pre-prepared text, so it is reasonable to reckon that the communication skills here work as automated skills. For our study, this approach would answer the question of whether communication skills are automated in social interaction. Videos are carefully worked on - authors have the opportunity to think through the text, proofread, edit it, bring it in line with the communication maxims. This approach is to show whether the authors of the texts take into account the need to comply with the maxim of communication. The choice of material thus provides 
an opportunity to clarify two aspects of the problem under analysis: whether the communication maxims are even taken into account in preparing for social interaction and whether the relevant skills are automated.

The form in which the objective and tasks were represented as well as the selected materials for the research requires the use of different methods of analysis. At the preparatory phase, different scientists` views on the definition of basic concepts (maxims of communication, social communication, social communicative interaction) were compared. The comparison helped to identify common features of definitions and differences in concepts, which were classified by type of information. Based on the obtained results, we substantiated our own interpretation of the basic concepts. At the initial phase, the main method was design practice (the content of known maxims was modelled on the terms of the social sphere), comparison (the content of maxims was compared with features of discourse), justification (the content of maxims for the social sphere was grounded). The second stage involved using generalization methods as the main one (the information about the essence and functions of social communications, value priorities of modern civilized society was generalized); modelling (the content of maxims, based on the conditions of social interaction and value priorities was modelled).

Resorting to particular methods was due not only to the tasks, but also the specificity of the material for analysis. Thus, from interviews given by authorities to journalists of some TV channels, statements were selected that illustrated the violation of the maxims of communication. The method of deliberate targeting was involved in this paper. Using the same method, we selected videos, in the text of which errors of non-compliance with the maxims of communication were recorded.

\section{DiSCUSSION AND CONCLUSION}

\section{A. Classification Principle}

We divided the well-known maxims of communication into two groups. The first includes the ones that define requirements for the organization of content and aimed at ensuring a full perception by the recipients. Such maxims got a detailed coverage in the works of G. Grice (1975): maxims of completeness, relevance, quality, and clarity. The second group included maxims that articulate demands for the moral climate of communication, the realization of the principle of politeness (maxims of tact, modesty, generosity, etc.) - they are justified in works of J. Leech (Leech 1983). To the same group, we attributed the maxim of politeness, stated in works of P. Brown and S. Levinson that is known as a principle of politeness (Brown \& Levinson, 1987).

Let us present the proposed classification in Table 1.

TABLE 1

CLASSIFICATION OF COMMUNICATION MAXIMS

\begin{tabular}{|l|l|}
\hline 1. Requirements for the content and organisation of the statement & 2. Requirements for a moral climate of communication \\
\hline Maxim of completeness & Maxim of tact \\
\hline Maxim of relevance & Maxim of modesty \\
\hline Maxim of quality & Maxim of generosity \\
\hline Maxim of clarity & Maxim of consent \\
\cline { 2 - 2 } & Maxim of approval \\
\cline { 2 - 2 } & Maxim of sympathy \\
\cline { 2 - 2 } & Maxim of politeness \\
\hline
\end{tabular}

\section{B. Maxims of the First Group}

Consider the maxims of the first group. In formulating the basic tenets in which the maxim of completeness is realized G. Grice guides speakers towards the selection of information in the necessary and sufficient amount, recommends submitting the most useful information. Addressees should understand everything (Who? What did? When? Where? Why? Etc.), but the message should not be anything superfluous. If we superimpose the content of this maxim into the social sphere, there is necessary to be clear about what information should be considered redundant. In our opinion, first of all, information that can lead to widespread anxiety, social disagreement without probable cause (protests, mass riots). It is also worth noting that if there is a good reason for protests, citizens have the right to disagree at peaceful assemblies (protest demonstrations, rallies, etc.). The events in Sanzhary (Ekspert pro 2020) became an example of mass anxiety, which grew into fear and provoked riots caused by the violation of the maxim of completeness. A case in point is that two postulates were not fulfilled at the same time in the news broadcast: the information of one type was insufficient (about the absence of danger to the population if treating patients with coronavirus in isolated hospitals), and the second type - too much (about dangerous consequences of the disease itself).

As superfluous, we deem the information that can offend citizens. However, this is already the subject for discussion of the maxims of the second group that is distinguished in the paper.

Insufficient information also causes no less harm to society. If the authorities do not explain their actions or do not notice the problem at all, citizens begin to simulate possible events in the hope of explaining the logic of actions of 
government officials to themselves, which always leads to negative phenomena: suspicions about government officials (perhaps unfounded), anxiety, etc.

So, to G. Grice's two postulates we add two more for social communications: 1. Do not report information that can provoke mass protests or riots without good reason. 2. In difficult, problematic situations, give citizens the necessary explanations for the actions of government agencies.

The maxim of relevance is realized only in one postulate and requires not to deviate from the topic of conversation in the discourse. In our opinion, in social communication, it is necessary to add one more postulate concerning headings to videos and the maintenance of messages in them: Ensure the compliance of the title and the content of the message. There are too many violations of this maxim in real communication on the Internet. Here are some examples.

Most of the video clips of the YouTube news channel "Rediska" show a mismatch between the title and the voiceover. For example, in video "It broke out! Urgently - the mercenaries ran away. Nothing will come out - they crossed over" (Spalakhnulo! 2020) it is said that the elections in ORDLO (SDDLR - separate districts of Donetsk and Luhansk regions) will not take place, that Russia is handing out passports to Ukrainians, that many have doubts about the causes of the fire in Luhansk region - the elements or arson, etc. Thus, the content of the message illustrates a complete deviation from the topic. Even taking into account the immense desire of the authors of the video to be viewed by as many users as possible, we cannot agree with such a violation of the maxim of relevance. And not only because such a flaw does not look professional, but also for another reason: misleading a user of the Internet with the title, the authors cause the effect of lack of expectations, which creates a kind of emotional discomfort for users of the Internet. The fact of discomfort is often noted by users themselves, who accuse the authors of the video of misinformation. There are numerous examples of such kind violation (Spalakhnulo! 2020; Zbyly! 2020; Terminovo! 2020).

As we can see, the content of the message illustrates a complete deviation from the topic. Even considering the motives of the authors of the video (they want to intrigue the recipient, to get as many users to watch the video as possible), one cannot agree with such a violation of the relevance maxim. Not only because it does not look professional, but also for another reason: by misleading Internet users with the title, the authors provoke a lack of expectation effect, which creates a kind of emotional discomfort for Internet users. The users themselves, accusing the authors of misinformation, often point out this discomfort.

The maxim of quality requires special consideration if it is superimposed on the social sphere of communication. Its postulates are so simple and clear that they do not require comment: 1. Do not say what you think is untrue. Parents teach their children not to lie from an early age. In communication theory, another postulate was added: Do not say what you do not have sufficient justification for. With regard to social communications, there is a need to clarify this postulate: Do not blame a person if you do not have documented evidence in the required amount. Unfortunately, the violation of the formulated requirement in real mass communication has been observed repeatedly. On television in the news, a person is accused of a crime (of course, at the request of government officials), and then the court releases him because there is no evidence. After things like this, the reaction of the public is predictable as they will accuse a person following the principle "when it rains, it pours" and the public suspects the authorities of corruption (following the principle "just got all pumped up"). Nobody knows the state of affairs, but the public is more inclined to be negative. Thus, accusing a person without evidence is superfluous information that excites public opinion. In this case, two maxims are violated: quality and completeness.

An original form of a lie is the concealment of facts - a violation often observed in the news. Mention should be made that hushing up is considered to be one of the forms of a lie, which was substantiated in his monograph by Paul Ekman (1985). As deliberate silencing often concerns political events, we leave this issue out of our attention. However, we emphasize that in the theory of communication, not only in connection with the maxims but also in relation to strategies that ensure the effectiveness of communicative interaction, it is strongly recommended to explain the logic of actions, rather than remain silent about them. We add the postulate of the maxim of quality for social interaction: Do not gloss over the facts, but give them a timely explanation!

The maxim of clarity of information, which is realized in four postulates, is related to speech literacy. Both its main postulate (Speak clearly!) and four clarifications can be qualified as the conditions of social communication. According to our observations, the violation of this maxim in social communication is rare, and if it occurs, it is not due to ignoring the known postulates, but due to lack of information.

\section{Maxims of the Second Group}

The maxims of the second group in the concept of J. Leach allow implementing the principle of politeness in real communication (1983). The principle of politeness has no limitations in the spheres of communication: it must be maintained in both interpersonal and social communication, but with regard to social communications, the maxims substantiated by J. Leech need some clarification. According to the concept of J. Leech, the maxim of tact forbids to raise topics that are unpleasant for the communication partner, if he himself did not start talking about relevant events or phenomena. In social communications, the requirement of tact should be interpreted in three ways, namely: 1) You cannot build statements that contradict universal moral values or national; 2) People cannot be insulted in their statements; 3) It is necessary to show respect for interlocutors, understanding of their problems. Here are examples of violations of the given maxims. 
In a civilized society, the equality of all people, the recognition of their right to life, is thought to be universal values. The human being and a person`s life and health, honor and dignity, inviolability as well as security are acknowledged as the highest social value in the entire civilized world. And when a female government official at a lecture tells students that a dysfunctional household gives birth to "defective" children, and women from such families should be sterilized, she violates these values. Moreover, the epithet "defective" used in relation to the children can still be regarded as an insult (Holova komitetu, 2020).

Two maxims are violated when a representative of the authorities calls the elderly corpses who should not be rescued:

"I urge not only the state but also the business of Ukraine to join and consciously make sure that our tests both express and serological - are mass for all Ukrainians. We know the statistics; how many people we have over 65. Although it is, unfortunately, the average life expectancy for men, in my opinion, is 65. So I will say frankly that the financiers who are supposed to help us are starting to count on those people who are still alive. I'm not kidding or scaring. I keep saying: you calculate how much money we need to allocate for living people, not for corpses" (Koronavirus: Yemets, 2020). (in bold we have highlighted).

The representative of the authorities makes a pessimistic prediction that all retirees will die from the coronavirus (Pomrut vsi pensioner, 2020).

There is a lack of respect for the interlocutor when a government official offers an old lady who complains of a lack of money to sell her dog in order to pay taxes (Deputat ot, 2020).

A complete misunderstanding of the problems of ordinary citizens is demonstrated by a government official who complains that she is not well-paid enough (though her salary of 36 thousand hryvnias, which is nine times the average salary) to afford herself to have a child (A mne khvataiet, 2020).

Other maxims of the second group are acceptable for social-communicative interaction, but with an emphasis on certain features. For the maxim of generosity, it is advisable to emphasize the undesirable dominance (Do not try to dominate in interaction with citizens). For the maxim of approval, it is desirable to highlight the positive direction of interaction: 1) Direct communication in a positive direction. 2) Avoid clarifying relationships in social interaction. The maxim of consent can be represented as follows: Build communication not on a dispute, but consent. Maxims of friendliness and modesty can be accepted without change.

Let us turn to the question of what maxims are due to the peculiarities of the discourse of social communication. All researchers emphasize that social communication is of paramount importance for society because the functions it is intended to perform are socially significant. Moreover, real-life events confirm the idea: as soon as a violation of the maxim of communication is tolerated in social interaction, public outrage or even unrest ensues. Thus, V. Rizun states: "Social communication is formed according to the laws of communication, but, like any technological thing, involves the use of scientific knowledge about communication and everything that is used to organize social communication business" (Rizun, 2012, p. 306) (in bold we have highlighted).

According to O. Kholod, social communication "focuses on exchanging of socially important information and regulation of social actions, interactions, and relations between social actors and objects in society" (Kholod, 2010, p. 278-279).

The maxims of social communication, substantiated by us, ensure compliance with all the criteria required by the conditions of social interaction. Thus, performing the analysis in two directions (from maxims to social discourse and vice versa), we obtained identical results, which confirm their reliability. However, in our opinion, there is a need to add a few more maxims that emphasize the specifics of the modern social context. Since social interaction accentuates universal moral values, the principles of equality of all citizens, democratic relations, the following maxims need to be added: 1) In social communications, focus on universal value priorities! 2) Express your democracy in communicative interaction!

\section{CONCLUSIONS}

The results of the research discussed in this article can be divided into three types: 1) those that confirmed the provisions substantiated by other authors; 2) those that added to the provisions substantiated by other authors; 3 ) those that are new. The material of our study, as well as observations of social events in Ukraine, confirmed such provisions, substantiated earlier by other authors:

- the importance and influence of communicative interaction in the social sphere;

- the need to observe the maxims of communication in social interaction.

The following observations and findings have complemented those validated by other authors:

- the presence of violations of the maxims of communication in social interaction;

- the identification of two types of communication maxims on the basis of direction.

The following results are new:

- types of violations of social interaction requirements in Ukrainian information space;

- two ways of modelling communication maxims for social communicative interaction;

- the content of communication maxims, aimed at the optimal organization of information;

- the content of the maxims of communication, aimed at providing the moral climate of social interaction. 
The analysis of Internet content confirmed that the well-known maxims of communication in the social sphere of interaction need to be adjusted according to the conditions of discourse and allowed to propose maxims of communication specific to social interaction. The maxims found in the paper were modelled in two ways: from wellknown maxims to the conditions of social discourse and from the conditions of social discourse and universal values to the maxims of communication. Both methods confirmed the correctness of adding maxims that are specific to social communication. The violation of the communication maxims was recorded in both prepared and unprepared speech, which indicates the need to build communicative competence among citizens of different social statuses.

Summarising the results of the study, we would like to point out that the maxims aimed at the optimal organisation of content are predominantly addressed to the authors of news programmes (verbal messages and videos). Let us formulate the main ones.

1) Do not report information that could provoke mass anxiety, social protests or unrest without good reason.

2) In complex, crisis situations, do not suppress the facts, but give citizens the necessary explanations for the actions of the authorities.

3) Ensure that the news headline corresponds to the content of the message.

The maxims, which provide a moral climate for communicative interaction, are addressed to representatives of organisations, institutions, authorities of various ranks, who have to give interviews in various situations. Three of them are expressed in the form of prohibitions and four in the form of recommendations.

Taboos:

1) Do not use expressions that contradict universal moral values or national values!

2) Do not insult people in expressions!

3) Do not try to dominate while interacting with citizens!

Guidelines:

1) Demonstrate respect for your interlocutors, understanding their problems.

2) Be guided by universal values!

3) Do not argue, but rather communicate in agreement.

4) Express your democratic nature in communicative interaction!

This research has also highlighted the prospects for further research into the stated theme: the validation of ways to popularise the specific requirements of communicative interaction in the social domain.

\section{REFERENCES}

[1] "A MNE KHVATAIET 4 TYSIACHI?»: UCHITELIA OTREAGIROVALI NA ZHALOBU MINISTRA NOVOSAD NA YEIO ZARPLATU [And I Have Enough for 4,000?": Teachers Reacted to Minister Novosad's Complaint about Her Salary] Retrieved July 6, 2020 from: https://delo.ua/econonomyandpoliticsinukraine/kak-uchitelja-i-socseti-otreagirovali-na-zhalobu-363739

[2] Adams, C. (2005). Social communication intervention for school-age children: Rationale and description. In Seminars in Speech and Language, 26(3), 181-188.

[3] American Speech-Language-Hearing Association (ASHA). Social Communication. Retrieved August 10, 2020 from: https://www.asha.org/public/speech/development/social-communication/\#about

[4] Brown, P., Levinson, S. (1987). Politeness: Some Universals in Language Usage. Cambridge: Cambridge University Press.

[5] Chaltas, T. (2016). Communications, career, and industry: The journey and the lessons. Journal of Professional Communication 4(2):29-34

[6] Chovganyuk, M.M. (2017). Verbalization of politeness strategies and tactics in an English-language television talk show. Kyiv - Zaporozhye, 107-113.

[7] "Deputat Ot «Slugi» Pensionerke: Prodayte Sobaku I Zaplatite Za Komunalku" (2020) [Deputy From The "Servant" To The Pensioner: Sell The Dog And Pay The Rent] Retrieved February 1, 2020 from: https://m.youtube.com/watch?v=2ebmQroJ0wI

[8] Eelen G. (2014). A Critique of Politeness Theory. London: Routledge. 298 p.

[9] Ekman, P. (1985). Telling Lies: Clues to Deceit in the Marketplace, Politics, and Marriage. New York-London: W. W. Norton \& Company. 390 p.

[10] Ekman, K. (2021). Making sense of sensing: Scaffolding community knowledge in an online informal scientific engagement. Learning, Culture and Social Interaction. Volume 30, Part A, 1-14.

[11] "Ekspert Pro Podii V Novykh Sanzharakh" (2020) [Expert On Events In New Sanzhary] Retrieved February 21, 2020 from: https://www.youtube.com/watch?v=mb9IPpvACFs

[12] Grice, H. P. (1975). 'Logic and conversation'. In: P. Cole and J. Morgan (eds) Studies in Syntax and Semantics III: Speech Acts, New York: Academic Press, 183-198.

[13] "HOLOVA KOMITETU VR Z PYTAN SOTSPOLITYKY TA ZAKHYSTU VETERANIV HALYNA TRETIAKOVA PID CHAS PUBLICHNOI ZUSTRICHI V KYIVSKII SHKOLI EKONOMIKY" (2020) [Head of the V.R. Committee on Social Policy and Veteran's Affairs Galina Tretiakova During a Public Hearing at the KYIV School of Economics] Retrieved June 26, 2020 from: https://cutt.ly/jfIuQeb

[14] Kholod, O. M. (2010). Spetsyfika tlumachennia termina «sotsialni komunikatsii». Zhurnalistyka v piari ta piar u zhurnalistytsi [Specifics of the term "social communities". Journalism in PR and PR in journalism] Kyiv: Hramota, 278-279.

[15] KORONAVIRUS: YEMETS NAZVAV POKOLINNIA 65+ "TRUPAMY" (2020) [Coronavirus: Yemec Called The 65+ Generation "Corpses"] Retrieved March 16, 2020 from: https://cutt.ly/EfIuFwi

[16] Leech, G. (1983). Principles of Pragmatics. London: Longman 
[17] Lutsenko, L.A. (2016). Strategies of positive politeness in the discursive practice of briefing. Philological Studios. Structure and Semantics of Linguistic Units. Vol. 14, $102-109$.

[18] "POMRUT VSI PENSIONERY". HLAVA MOZ ZROBYV PROHNOZ SHCHODO KORONAVIRUSU, ALE POTIM VIBACHYVSIA (2020) ["All Pensioners Will Die". the Head of the MHC Made a Prognosis about the Coronavirus, but He Was Sorry for It] Retrieved March 14, 2020 from: https://cutt.ly/XfliSfw

[19] Prus, L.V. (2015). Communicative deviations caused by the violation of the principle of cooperation. Philological Studios. Collection of scientific works. Issue 5, $98-101$.

[20] Rizun,V. (2012). Sotsialni komunikatsii yak inzhenerne vchennia, abo sotsialni komunikatsii v systemi sotsialnoho inzhynirynhu (sotsialnoi inzhenerii) [Social communities as engineering sciences, or social communities in the system of social engineering]. Komunikatsiia, 2, 8-18.

[21] Robinson, J (2016). Accountability in social interaction. In: Robinson, J (ed.) Accountability in Social Interaction. New York: Oxford University Press, $1-44$

[22] "SPALAKHNULO! TERMINOVO - NAIMANTSI POBIGLI. NICHOGO NE VIYDE - VONI PEREISHLI" (2020) [It flared up! urgently - the mercenaries ran. It's not going to work - they've crossed] Retrieved June 10, 2020 from: https://cutt.ly/ugFsnsF

[23] "TERMINOVO! NAIMANTSI POPERLY - POTUZHNII OBSTRIL, VSIOMU KINETS. ZHORSTKA VIDSICH - VONY RUKHNULY" (2020) [Urgent! The mercenaries have popped - heavy shelling, it's all over. A brutal response - they collapsed] Retrieved September 10, 2020 from: https://cutt.ly/qfIopPf

[24] Zarytska, V. M. (2018). Problemy ta perspektyvy vitchyznianoho menedzhmentu v konteksti yevrointehratsii [Problems and prospects of domestic governance in the context of European integration] Suchasnyi menedzhment: modeli, stratehii, tekhnolohii [Modern Management: Models, Strategies, Technologies] Odesa: ORIDU NADU, 36-38.

[25] “ZBYLY! ULAMKY ROZKYDALO NA KILOMETRY, ROSIIA PONESLA VAZHKU VTRATU: DOBRA ZVISTKA PID VECHIR" (2020) [They were shot down! Wreckage scattered for kilometers, RUSSIA suffered heavy losses: good news tonight] Retrieved September 9, 2020 from: https://cutt.ly/ufIoul9

Margaryta O. Zaitseva defended her PhD thesis in the Russian language at Kharkiv National Pedagogical University) named after G.S. Skovoroda in 2002. Then in 2003 she was awarded the title of Associate Professor. Now she works as Associate Professor at Department of Foreign Languages No 2, Yaroslav Mudryi National Law University in Kharkiv.

Sphere of her academic interests: communication theory, social communication, cognitive linguistics, and courtroom discourse

Lyudmyla M. Pelepeychenko defended her PhD thesis in the Russian language at V.N. Karazin Kharkiv National University in 1988. The same year she was awarded the title of Associate Professor. In 1996 she successfully defended her doctoral thesis in Russian language at the Institute of Linguistics named after O.O. Potebnya of the National Academy of Sciences of Ukraine. In 1997, she was awarded the title of Doctor in Philology and she began to work as Full Professor in the Department of Linguistics. She now works as a professor in the Department of Philology, Translation and Strategic Communications, National Academy of the National Guard of Ukraine in Kharkiv.

Sphere of her academic interests: communication theory, social communication, cognitive and pragmatic aspects of language units, and formation of communicative competence of cadets. 